\title{
Reflective Learning Views of Students, Teachers and Instructors: A Mixed-Methods Study
}

\author{
Irfan Tosuncuoglu ${ }^{1}$ \\ ${ }^{1}$ Department of English Language and Literature, Karabük University, Karabük, Turkey \\ Correspondence: Irfan Tosuncuoglu, Department of English Language and Literature, Karabük University, \\ 78050 Karabük, Turkey.
}

Received: January 11, 2019

Accepted: February 16, 2019 Online Published: February 18, 2019

doi: $10.5539 /$ elt.v12n3p200

URL: https://doi.org/10.5539/elt.v12n3p200

\begin{abstract}
Teachers need to modernize themselves and keep pace with changes in order to adapt themselves to the developing and changing system. At this juncture, the "reflective learning" model becomes an important element of teachers' professional development. Since the concept of reflection was first used, it has increased its importance as an alternative approach to the existing models of learning that still hold sway. Nevertheless, when the studies that have been conducted over the years were consulted, it was determined that reflective learning is a difficult concept to define, because reflection is an abstract concept, the question how it is to be distinguished from one's other thoughts and ideas assumes importance. For this reason, research with 102 participants has been undertaken in order to ascertain the awareness of teachers, students and instructors of reflective learning. The participants are broken down thus: 35 students receiving education in the English Language and Literature department of Karabük University; 31 instructors providing in-service English classes in the same university's Preparatory unit and other Faculties; and 36 English teachers serving in the secondary level schools in the Karabük province in Turkey. The participants have responded to a survey consisting of 33 questions. In the data analysis, SPSS and nonparametric Mann-Whitney-U, Kruskal-Wallis and Student Newman Kleus tests have been used. In addition, 2 teachers have been interviewed, the technique of content analysis has been used and the data has been analyzed by means of NVivo 12 Pro - computer assisted qualitative data analysis programme.
\end{abstract}

Keywords: English language, instructor, reflective learning, student, teacher

\section{Introduction}

The 21 st century can be observed and described as fast changes and developments occurring in the areas of our lives. Meanwhile, teaching has not stayed indifferent to this unexpected speed of advancements and information technology. All teachers need to keep up with the subjects of curriculum tendencies, foreign or second language teaching and learning studies; and testing-assessments (Richards \& Farrell, 2005) have knowledge that educational methods and practices are constantly developing. Evaluation of student profiles and needs must be more extensive (Büyükyavuz, 2016). Besides this, one of the aims of teaching is to teach thinking performance to students (Semerci, 1999). Therefore, in order for teachers to be equipped with the professional capabilities and skills that will support them in teaching more and more actively, they need to constantly keep learning within their fields in compliance with the changing world conditions.

At the same time, teachers need to have recourse to different ways oriented towards improving themselves in order to meet the demands their profession expects from them. As expected, the argument putt forth that professional development should be "intensified, continuous and linked with practical application" (Darling-Hammond et al., 2009) and the reflective learning model, which is in the same vein, are increasingly becoming popular. At this juncture, "reflective learning" becomes an important factor in teachers' professional development.

Since reflective learning has become popular, confusion has arisen with regard to what it entails in actuality and it began to be criticized for becoming a slogan expression that lost its necessity (Burton, 2009). Nowadays, research on language teaching has shifted to the contributions of the students, teachers and the larger socio-political context. According to Kumaravadivelu (2006) and Ryder (2012), this change played a role in research on reflective teaching in language teaching. 
When the studies that have been conducted over the years were consulted, reflection was found to be a difficult concept to define. Since reflection is an abstract concept, the question how it is to be distinguished from one's other thoughts and ideas assumes importance. If the teacher is to make an evaluation in order to get feedback concerning her own teaching, what, how and how much will she think and evaluate? In order for her to make such an evaluation, there needs to be a clear definition of reflection and there also needs to be assessment criteria. Since there is no such definition, some use the concept of reflection, some use the concept of critical thinking and some use the concept of assessment (Ügüten \& Ekizer, 2017).

On the other hand, Zeichner and Liston (1996) warned that if a teacher does not question the objectives and values guiding their practice, setting and context in which they provide teaching, or does not examine their own assumptions, their way of thinking cannot be characterized as reflective.

Reflective practice also allows teachers to be free from either impulsive or standard behaviors. As for reflective thinking; it is necessary for teachers to control teaching processes and be effective decision makers (Osterman \& Kottkamp, 2004). Also, some of the researchers think that it is only by means of the teachers' reflections of their teaching activities that they become more and more well-qualified practitioners who can define their role in the context of educational aims (Zeichner \& Liston, 1996). In this vein, what it is meant by the notion of 'reflective practitioner' can be clarified. Generally, in this study, reflective learning and related concepts and issues will be scrutinized, and the findings of scientific studies will be evaluated in detail.

\section{A Reflective Practitioner}

Schön (1983, 1991), Kinsella (2001), Kemmis (2011) are among the scientists who rendered the concept of "reflective practitioner" to be most popular. Kumaravadivelu (2003) brings a detailed classification to the roles of teacher as touched upon in the related literature such as: teachers as a passive technique practitioner; teachers as a reflective practitioner; teachers as a transformative intellectual. In the literature, despite these teacher roles being available before Kumaravadivelu's classification, the contribution that he made is important as it enables the reader to denote the roles of teachers holistically. Kumaravadivelu's (2003) classification is of particular importance in this study as it is the primary source that this paper draws on.

According to Dewey $(1993,1997)$ on the other hand, a reflective teacher has 3 distinctive qualities: open-mindedness, responsibility and sincerity. Open-mindedness entails being tolerant of various kinds of ideas and not viewing these ideas as drawbacks. Open-minded individuals assess their immediate convictions when they face new info; in this situation they are open to agree with the chances of making mistakes. These individuals agree with the reality that they may likely not be right, and they are not competing to get the upper hand in a discussion (Larrivee, 2008). They are able to criticize themselves. An open-minded reflective teacher is ready to hear the different opinions of their learners' and colleagues' and they have the ability to direct their beliefs and teaching styles and techniques according to various conditions. Borg (2011) expresses the view that reflective teachers systematically examine their teaching practices and thus acquire new discernments and elevate their teaching quality.

In other respects, teaching can be generally defined as an interactive process, because teachers consciously or unconsciously shape their teaching according to various factors such as students' profiles, ages and past experiences. When they undertake a teaching activity, most of the time teachers get involved in a thinking process in order to evaluate the results and outcomes of these activities. This process can be defined as reflection or reflective practice. Further, during this process, teachers employ various strategies to update their teaching styles; for example, correction strategies used by the teachers in the classrooms, how to improve students' positive attitudes toward learning EFL, and how to improve their own motivations (Han \& Mahzoun, 2017; Han, Tanriöver, \& Şahan, 2016).

In this context, Schön (1983) distinguished reflective practices into 2 categories: reflection-on-action, which equates to the evaluation of past experiences; and reflection-in-action which occurs simultaneously at the time of teaching. As this classification still receives recognition from many researchers, Van Manen made a contribution to the field in 1991 by adding another category called reflection-for-action. Van Manen developed this category which is based on evaluating the existing experience and making inferences about future situations and problems - thinking that Schön's reflection does not take the future actions into consideration.

\section{Reflective Learning}

Reflective learning can be applied by means of various approaches like action research, teaching logs, concept mapping, groups of discussions, critical friendship, self-observation and peer class observation, attentive checking of lesson plans and analyses of class videos (Farrell, 2008). 
While several of the approaches above can be applied easily while teachers are conducting a lesson in the class, some others can be applied only afterwards. Schön (1991) prefers the expressions "reflection-in-action" and "reflection-on-action" in order to describe these 2 conditions respectively. A third situation put forth by Farrell (2016) refers to being in the state of reflection before conducting a class (reflection-for-action). Checking a lesson plan before applying it in the class is a relevant example of this kind of reflection.

The frameworks suggested for the classification of reflection types define the concept of reflective practice as a combination of theoretical knowledge and the experience of a purposeful thinking process. In order to run this process, different tools were used such as reflective journals (Boud, 2001; Lee, 2007) and portfolios (Whitton, Sinclair, Barker, Nanlohy, \& Nosworthy, 2004) in various studies. Other than this, in the last 40 years, various researchers have developed theoretical frameworks with the purpose of analyzing the functions and contributions of teachers in reflective practice, in order to be able to observe the role of reflection on the professional development of teachers. Kolb's model of experimental learning, Boud, Keogh \& Walker's reflection model, Brookfield's model of critical thinking and Gibbs' model of reflective cycle are some samples reported by Rivers, Richardson and Price (2014).

\section{Learning Strategies and Reflection}

There are certain psychological dimensions of the differences between students in terms of learning strategies. These dimensions are multiplexed and manifold. Just like students' personalities, affective factors may also affect the degree of their concern and their readiness to take risks while learning a second language. Students' styles of learning may affect their holistic adaptation to the learning task and be effective on the input type that they find it the easiest to study with (Ellis, 2003).

People think, act and learn in different ways from each other. When we examine the root of students' learning styles, Asbury et al. (2014) and Dunn and Griggs (1998, cited in Coffield et al., 2004) put forth that at the basis, learning styles are correlated with students who have the same potential, biological characteristics and series of developmental properties; and in addition, while certain teaching methods prove ideal for some students they can prove inadequate for others. Therefore, learning styles can be impacted by students' genes and genetic makeup, their experiences regarding learning activities, their cultural accumulations and the societies in which they reside.

For this reason, a teacher has a serious responsibility in improving their own teaching style in order to support the possibilities of extending the students' learning styles. According to Friedman and Alley (1984), the situations in which teachers prove most beneficial are those in which they help the students determine their own learning styles and learn through their style of preference. For this reason, the teacher has a difficult job in determining their own teaching role.

Differences in the ways of behaving and thinking are apparent in the area of teaching as in most other areas. Reflection is an important part of learning and teaching experiences (Tok, 2008). Reflection is currently one of the most important concepts in education. Fundamentally, the concept of reflection was explained by Dewey in 1933 in order to explicate the subject of education deeply and steer it, dealing with its practitioners' practical problems and striving to produce realistic solutions suitable for them while referring to the active, purposeful and consistent process of thinking.

Since the concept of reflection was first used by John Dewey in the years 1910 to 1933, it has increased its significance as an alternative approach to the existing teacher training models that still hold sway. Because it helps teachers in transferring their pedagogical knowledge into their teaching experience, it is being used as a tool in practice-based professional learning. Richards (1998) considers reflectivity as an important part of teacher development. Richards and Farrell (2005) put forth in the same vein that reflectivity is the process of critically evaluating experiences and that it is a process that leads to a better understanding of teaching.

\section{Reflective Thinking}

Reflective thinking is a philosophical concept that is constantly evolving and that is quite frequently used in teacher training. Dewey (1933) defines the concept of reflective thinking as "active, persistent, conscious, systematic, constant and careful thinking in the light of any thought or presupposed type of knowledge and the results it is oriented towards." Vygotsky (1978) does not make a direct definition of the concept of reflective thinking. Nonetheless, Vygotsky makes a distinction between lower and higher mental functions. As he explains this, he states that higher mental functions do not automatically emerge as children mature. The formation of these skills is based on the societal conditions in which children and adolescents find themselves. The origin of higher mental functions does not reside in individuals but in social relations and practices such as (1) 
collaboration with more capable adults and peers, (2) school education and (3) the formation of scientific concepts.

In the 21st century, one of the skills that has fundamental importance and appeal for young people is reflective thinking (Hanushek \& Woessmann, 2008; Lantolf \& Poehner, 2014; Zukerman, 2016). Reflective thinking refers to the "criticism of the problem-solving process and content" in order to test the validity of pre-existing knowledge. Therefore, reflective thinking generally leads to a change in the individual's way of perception, sense and behavior (Mezirow, 1991, p. 105). Reflective thinking has a deeper level that is called critical reflection (Kember, et al., 2000). Critical reflective thinking is expressed as "the evaluation of how and why we perceive, think or take action in certain ways." Thus, it requires an awareness regarding that a person's perspectives, beliefs, knowledge and expectations are "acquired in childhood away from criticism through the process of socialization" (Mezirow, 1990, p. 1).

In cultural-historical psychology, the content of scientific disciplines and collaboration with peers are both very important in terms of developing reflection as a thinking skill. Davydov (1990) and Zuckerman (2003) suggest that collaboration with peers is "the necessary condition for the development of reflective skills". In teaching types where the relevant learning objectives (skills, concepts) are acquired through the imitation of a model provided by the teacher, the control and monitoring of concordance between performance and the model presented is generally carried out by the teacher.

Besides, it is clear that imitation does not involve hypotheses and questions concerning unknown or contradictory realities. As a consequence, the responsibility of reflection crosses over onto the adult. Teachers need to design learning tasks that can encourage different perspectives or different methods of problem solving. During these types of tasks, students resolve the contradictions in their thoughts or perspectives without the intervention of the teacher. In the process of bringing different perspectives into consonance and scrutinizing them, students may view the subject in discussion from different angles and develop a more versatile approach by distancing themselves from their primary perspectives (Zuckerman, 2003, p. 193).

\section{Aim of the Research}

As mentioned earlier, since the concept of reflective learning was first used, it has increased its importance as an alternative approach to the existing models of learning that still hold sway and it was determined that it is a difficult concept to define. For this reason, a survey study has been implemented in order to ascertain the awareness of teachers, students and instructors of reflective learning

\section{Method}

\subsection{The Nature of the Research}

This research basically has both quantitative and qualitative characteristics. The research includes quantitative research, for which a survey model was used. And, qualitative researchers use basically 3 types of techniques: observing the people as they go about their routine common activities; realizing deep interviews with people about their ideas, etc.; and analysis of documents or other kinds of communication (content analysis). Content analysis developed in the field of communication but is now widely used across the disciplines. Some refer to content analysis as a way of studying documented human communications (Adler \& Clark, 2011; Babbie, 2013).

\subsection{Participants}

The survey was carried out in 2018-2019 academic year. In total there were 102 participants: 35 students receiving education in the English Language and Literature department of Karabük University; 31 instructors providing in-service English classes in the same university's Preparatory unit and other Faculties; and 36 English teachers serving in the secondary level schools in the Karabük province. There were 36 male and 66 female participants who all took part in the survey voluntarily. In addition to this, 2 teachers from the secondary schools were interviewed. Since the foundations of the language teaching process are initially laid in secondary education, 2 one-to-one interviews with 2 English teachers who serve in secondary schools were preferred.

\subsection{Instrumentation and Data Collection}

In the data analysis, SPSS and nonparametric Mann-Whitney-U and Kruskal-Wallis test have been used. Besides this a multiple comparison test called "SNK (Student Newman Kleus test or Post Hoc test)" was also used for multiple comparisons.

The participants responded to a survey consisting of 33 questions (questionnaire) adapted from Xu et al. (2015), its validity was confirmed. These 33 closed-end statements were designed on a 5-point Likert scale: 1 (strongly disagree), 2 (disagree), 3 (undecided), 4 (agree), 5 (strongly agree). There were sub dimensions adapted from 
Akbari (2010) et al.'s tentative model in the survey; Practical (pract), Cognitive (cog), Meta-cognitive (meta), Critical thinking (crit), Affective learning (affect), Moral (moral), Classroom management (classman).

In addition, as mentioned before, 2 teachers of English were interviewed and the technique of content analysis was used by the help of NVivo 12 Pro programme in the evaluation of the data obtained. NVivo 12 Pro is a computer assisted qualitative data analysis programme, it is used in the evaluation of the qualitative data.

The foundations of the language teaching process are initially laid in secondary education, namely secondary school and high school, 2 one-to-one interviews in person were done on a volunteer basis with 2 English teachers who serve in secondary schools in order to ascertain the perception of teachers on the subject of reflective learning. The responses of the teachers were audio-recorded.

\subsection{Participant Distribution and Findings}

Survey results of 102 subjects were analyzed of which are $36(\% 35.3)$ were males and $66(64.7)$ were females.

Table1. Distribution of profession and experience

\begin{tabular}{|c|c|c|c|c|c|c|}
\hline & & & \multicolumn{3}{|c|}{ profession } & \multirow[b]{2}{*}{ Total } \\
\hline & & & student & teacher & instructor & \\
\hline \multirow[t]{12}{*}{ experience } & $0-5$ & Count & 6 & 18 & 3 & 27 \\
\hline & & $\%$ of Total & $5.9 \%$ & $17.6 \%$ & $2.9 \%$ & $26.5 \%$ \\
\hline & $6-11$ & Count & 0 & 4 & 12 & 16 \\
\hline & & $\%$ of Total & $0.0 \%$ & $3.9 \%$ & $11,8 \%$ & $15.7 \%$ \\
\hline & $12-17$ & Count & 0 & 3 & 6 & 9 \\
\hline & & $\%$ of Total & $0.0 \%$ & $2.9 \%$ & $5.9 \%$ & $8.8 \%$ \\
\hline & $18-23$ & Count & 0 & 2 & 2 & 4 \\
\hline & & $\%$ of Total & $0.0 \%$ & $2.0 \%$ & $2.0 \%$ & $3.9 \%$ \\
\hline & 24 over & Count & 1 & 8 & 8 & 17 \\
\hline & & $\%$ of Total & $1.0 \%$ & $7.8 \%$ & $7.8 \%$ & $16.7 \%$ \\
\hline & missing & Count & 28 & 1 & 0 & 29 \\
\hline & & $\%$ of Total & $27.5 \%$ & $1.0 \%$ & $0.0 \%$ & $28.4 \%$ \\
\hline \multirow[t]{2}{*}{ Total } & & Count & 35 & 36 & 31 & 102 \\
\hline & & $\%$ of Total & $34.3 \%$ & $35.3 \%$ & $30.4 \%$ & $100.0 \%$ \\
\hline
\end{tabular}

Approximately $28 \%$ of the attendees didn't answer the question related to experience. For experience, a total of 73 answers were provided out of 102 .

The difference of mean attendance level between male and female was analyzed by nonparametric Mann-Whitney-U test. The descriptive statistics and test results are given in Table 2 for 7 sub-dimensions.

Table 2. The descriptive statistics and test results in terms of gender

\begin{tabular}{lllllll}
\hline & gender & $\mathrm{N}$ & Mean & Std. Deviation & Std. Error Mean & Asymp. p (2-tailed) \\
\hline pract & male & 36 & 3.1574 & .81838 & .13640 & 0.129 \\
& female & 66 & 3.4141 & .69935 & .08608 & \\
$\operatorname{cog}$ & male & 36 & 3.7500 & .76997 & .12833 & 0.915 \\
& female & 66 & 3.8232 & .62763 & .07726 & \\
meta & male & 36 & 39611 & .70398 & .11733 & 0.846 \\
& female & 66 & 3.9818 & .58570 & .07210 & 0.616 \\
crit & male & 36 & 3.7994 & .71112 & .11852 &
\end{tabular}




\begin{tabular}{lllllll}
\multirow{2}{*}{ affec } & female & 66 & 3.8906 & .55624 & .06847 & \\
& male & 36 & 3.9611 & .71365 & .11894 & 0.871 \\
\multirow{3}{*}{ moral } & female & 66 & 3.9636 & .57208 & .07042 & \\
& male & 36 & 3.7778 & .69902 & .11650 & 0.248 \\
\multirow{2}{*}{ classman } & female & 66 & 3.9424 & .66171 & .08145 & \\
& male & 36 & 4.2222 & .80079 & .13347 & 0.824 \\
& female & 66 & 4.2475 & .56178 & .06915 & \\
\hline
\end{tabular}

According to the non-significant $p$-values $(p>\alpha=0.05$ ), there is no statistically significant difference detected between male and female by mean attendance level in any of the 7 sub-dimensions.

In general, both male and female are indecisive about the items of "practical (pract)" subgroup whereas they both agree on the items of "cognitive (cog)", "meta-cognitive (meta)", "critical thinking(crit)", "affective learning (affec)", "moral (moral)" and "classroom management (classman)" subgroups.

The difference of mean attendance level between student, teacher and instructor was analyzed by nonparametric Kruskal-Wallis test. The descriptive statistics and test results are given in Table 3 for 7 sub-dimensions.

Table 3. The descriptive statistics and test results in terms of student, teacher and instructor

\begin{tabular}{|c|c|c|c|c|c|c|}
\hline & & $\mathrm{N}$ & Mean & Std. Deviation & Std. Error Mean & Asymp. p (2-tailed) \\
\hline \multirow[t]{4}{*}{ pract } & student & 35 & 3.2667 & .70386 & .11897 & \\
\hline & teacher & 36 & 3.4444 & .78072 & .13012 & 0.527 \\
\hline & instructor & 31 & 3.2473 & .76965 & .13823 & \\
\hline & Total & 102 & 3.3235 & .74971 & .07423 & \\
\hline \multirow[t]{4}{*}{$\operatorname{cog}$} & student & 35 & 3.5619 & .75308 & .12729 & \\
\hline & teacher & 36 & 3.9444 & .59362 & .09894 & \\
\hline & instructor & 31 & 3.8925 & .62886 & .11295 & 0.120 \\
\hline & Total & 102 & 3.7974 & .67837 & .06717 & \\
\hline \multirow[t]{4}{*}{ meta } & student & 35 & 3.7714 & .73907 & .12492 & \\
\hline & teacher & 36 & 4.0833 & .55214 & .09202 & 0.155 \\
\hline & instructor & 31 & 4.0774 & .52327 & .09398 & \\
\hline & Total & 102 & 3.9745 & .62659 & .06204 & \\
\hline \multirow[t]{4}{*}{ crit } & student & 35 & 3.5968 & .73953 & .12500 & \\
\hline & teacher & 36 & 3.9043 & .50336 & .08389 & \\
\hline & instructor & 31 & 4.1004 & .45664 & .08202 & $0.013^{*}$ \\
\hline & Total & 102 & 3.8584 & .61341 & .06074 & \\
\hline \multirow[t]{4}{*}{ affec } & student & 35 & 3.7257 & .73258 & .12383 & \\
\hline & teacher & 36 & 4.1111 & .52251 & .08708 & \\
\hline & instructor & 31 & 4.0581 & .52458 & .09422 & $0.035^{*}$ \\
\hline & Total & 102 & 3.9627 & .62218 & .06161 & \\
\hline \multirow[t]{4}{*}{ moral } & student & 35 & 3.7886 & .77299 & .13066 & \\
\hline & teacher & 36 & 3.8500 & .64209 & .10702 & \\
\hline & instructor & 31 & 4.0323 & .58900 & .10579 & 0.508 \\
\hline & Total & 102 & 3.8843 & .67630 & .06696 & \\
\hline classman & student & 35 & 3.9048 & .76940 & .13005 & \\
\hline
\end{tabular}




$\begin{array}{lllll}\text { teacher } & 36 & 4.3704 & .53912 & .08985 \\ \text { instructor } & 31 & 4.4624 & .46886 & .08421 \\ \text { Total } & 102 & 4.2386 & .65228 & .06459\end{array}$

$0.002 *$

Note. *: significant at $\alpha=0.05$

Depending on the test results, it can be said that, there are statistically significant differences between 3 profession levels by the mean attendance level of "critical thinking (crit)", "affective learning (affec)" and "classroom management (classman)" ( $<<\alpha=0.05)$.

For the items of "critical thinking (crit)", the mean attendance level of student is lower than teacher and instructor $\left(\bar{x}_{\text {student }}=3.5968\right)$.

For Multiple comparisons of the sub dimensions Student Newman Kleus test was implemented.

\section{Critical thinking (crit)}

Student-Newman-Keuls ${ }^{\mathrm{a}, \mathrm{b}}$

\begin{tabular}{llll}
\hline & & \multicolumn{2}{l}{ Subset for alpha $=0.05$} \\
\cline { 3 - 3 } profession & $\mathrm{N}$ & 1 & 2 \\
student & 35 & 3.5968 & 3.9043 \\
teacher & 36 & & 4.1004 \\
instructor & 31 & & .170 \\
Sig. & & 1.000 & \\
\hline
\end{tabular}

Similarly, for the items of "affective learning (affec)", the mean attendance level of student is lower than teacher and instructor $\left(\bar{x}_{\text {student }}=3.7257\right)$.

Affective learning (affec)

Student-Newman-Keuls ${ }^{\mathrm{a}, \mathrm{b}}$

\begin{tabular}{llll}
\hline & & \multicolumn{2}{l}{ Subset for alpha $=0.05$} \\
\cline { 3 - 3 } profession & $\mathrm{N}$ & 1 & 2 \\
student & 35 & 3.7257 & 4.0581 \\
instructor & 31 & & 4.1111 \\
teacher & 36 & & .718 \\
Sig. & & 1.000 & \\
\hline
\end{tabular}

For the items of "classroom management (classman)", the mean attendance level of student is lower than teacher and instructor $\left(\bar{x}_{\text {student }}=3.9048\right)$.

\section{Classroom management (classman)}

Student-Newman-Keuls ${ }^{\mathrm{a}, \mathrm{b}}$

\begin{tabular}{llll}
\hline & & \multicolumn{2}{l}{ Subset for alpha $=0.05$} \\
\cline { 3 - 3 } profession & $\mathrm{N}$ & 1 & 2 \\
student & 35 & 3.9048 & \\
teacher & 36 & & 4.3704 \\
instructor & 31 & & 4.4624
\end{tabular}


Sig.

1.000

.537

For the 3 sub-dimensions mentioned above, no statistically significant differences are detected between teacher and instructor.

The difference of mean attendance level between 5 experience levels was analyzed by nonparametric Kruskal-Wallis test. The descriptive statistics and test results were given in Table 4 for 7 sub-dimensions.

Table 4. The descriptive statistics and test results in terms of experience

\begin{tabular}{|c|c|c|c|c|c|c|}
\hline & & $\mathrm{N}$ & Mean & Std. Deviation & Std. Error Mean & Asymp. p (2-tailed) \\
\hline \multirow[t]{6}{*}{ pract } & $0-5$ & 27 & 3.5802 & .54375 & .10464 & 0.188 \\
\hline & $6-11$ & 16 & 3.0208 & .85608 & .21402 & \\
\hline & $12-17$ & 9 & 3.3333 & .89753 & .29918 & \\
\hline & $18-23$ & 4 & 3.2500 & .50000 & .25000 & \\
\hline & 24 over & 17 & 3.4510 & .86555 & .20993 & \\
\hline & Total & 73 & 3.3790 & .75628 & .08852 & \\
\hline \multirow[t]{6}{*}{$\operatorname{cog}$} & $0-5$ & 27 & 3.9753 & .56179 & .10812 & 0.481 \\
\hline & $6-11$ & 16 & 3,9375 & .62324 & .15581 & \\
\hline & $12-17$ & 9 & 3.7778 & .70711 & .23570 & \\
\hline & $18-23$ & 4 & 4.2500 & .50000 & .25000 & \\
\hline & 24 over & 17 & 3.7255 & .56808 & .13778 & \\
\hline & Total & 73 & 3.8995 & .59235 & .06933 & \\
\hline \multirow[t]{6}{*}{ meta } & $0-5$ & 27 & 3.9704 & .61445 & .11825 & 0.732 \\
\hline & $6-11$ & 16 & 4.0250 & .56036 & .14009 & \\
\hline & $12-17$ & 9 & 4.2000 & .48990 & .16330 & \\
\hline & $18-23$ & 4 & 4.0500 & .52599 & .26300 & \\
\hline & 24 over & 17 & 4.2000 & .44159 & .10710 & \\
\hline & Total & 73 & 4.0685 & .54183 & .06342 & \\
\hline \multirow[t]{6}{*}{ crit } & $0-5$ & 27 & 3.8807 & .54514 & .10491 & 0.789 \\
\hline & $6-11$ & 16 & 3.9931 & .44160 & .11040 & \\
\hline & $12-17$ & 9 & 4.1358 & .52932 & .17644 & \\
\hline & $18-23$ & 4 & 4.0833 & .55463 & .27731 & \\
\hline & 24 over & 17 & 4.0196 & .40869 & .09912 & \\
\hline & Total & 73 & 3.9802 & .48656 & .05695 & \\
\hline \multirow[t]{6}{*}{ affec } & $0-5$ & 27 & 3.9556 & .58791 & .11314 & 0.355 \\
\hline & $6-11$ & 16 & 3.9125 & .50050 & .12512 & \\
\hline & $12-17$ & 9 & 4.2000 & .52915 & .17638 & \\
\hline & $18-23$ & 4 & 4.2000 & .63246 & .31623 & \\
\hline & 24 over & 17 & 4.2118 & .40293 & .09772 & \\
\hline & Total & 73 & 4.0493 & .52787 & .06178 & \\
\hline \multirow[t]{3}{*}{ moral } & $0-5$ & 27 & 3.7704 & .70319 & .13533 & 0.295 \\
\hline & $6-11$ & 16 & 3.8375 & .58977 & .14744 & \\
\hline & $12-17$ & 9 & 4.2667 & .54772 & .18257 & \\
\hline
\end{tabular}




\begin{tabular}{lllllll}
\multirow{5}{*}{ classman } & $18-23$ & 4 & 4.1000 & .52915 & .26458 & .12589 \\
& 24 over & 17 & 3.9765 & .51905 & .07246 & 0.877 \\
& Total & 73 & 3.9123 & .61913 & .12014 & \\
& $0-5$ & 27 & 4.2469 & .62424 & .10852 & .16769 \\
& $6-11$ & 16 & 4.4375 & .43408 & .40825 \\
& $12-17$ & 9 & 4.5185 & .50308 & .11242 & \\
& $18-23$ & 4 & 4.3333 & .81650 & .06334 & \\
\hline
\end{tabular}

Depending on the test results, it can be said that, there isn't any statistically significant effect of the experience on the mean attendance level of none of the 7 sub-groups $(p>\alpha=0.05)$.

\subsection{Interview}

As mentioned before, since the foundations of the language teaching process are initially laid in secondary education, namely secondary school and high school, 2 one-to-one interviews in person were done on a volunteer basis with 2 English teachers who serve in secondary schools in order to ascertain the perception of teachers on the subject of reflective learning. The responses of the teachers were audio-recorded. While the first English teacher (Teacher 1) has 20 years of experience, the second teacher (Teacher 2) has 8 years of experience. In addition to these 2 teachers being interviewed, the technique of content analysis was used in the evaluation of the data obtained.

1) How do you understand reflective teaching? Do you think it helps improve your teaching?

Teacher 1. As far as I know, it refers to placing importance on somebody else's opinion. I think it is definitely beneficial. And I think it facilitates learning.

Teacher 2. Reflective learning is valid for both sides, namely both the teacher and the student. I know that this is already the approach that was put forth by John Dewey.

Teachers in practicality know how to be a reflective teacher.

2) Are you a reflective teacher? What do you usually reflect on?

Teacher 1. I can consider myself to be a reflective teacher, I can question where I made mistakes. I frequently ask these questions. I also want students to question themselves. In this sense, I can understand how they learn better since I steer them towards questioning themselves.

Teacher 2. I am a reflective teacher, instead of providing them with the subject, I would prefer to provide them with the grammar via exercises and then provide them with the rules.

Teachers consider themselves as reflective teachers.

3) How do you reflect in and out of the classroom?

Teacher 1. I would like my students to evaluate how they see each other in the class and out of class. They can draw advantages from each other by observing how each other learns.

Teacher 2. I understand this from the feedback I receive. For instance, I enter the classroom with surprising or attention-grabbing material. The students try to understand what it is. If I am going to talk about organs, I would bring relevant materials. If I see any student outside the class, I address them in English.

Teacher 1 considers individual evaluation and Teacher 2 gives importance to the authentic materials

4) Do you provide equal opportunities for all your students in the class?

Teacher 1. I believe that I provide equal opportunities for everyone. If they are enthusiastic, they can take advantage of these opportunities. However, sometimes the classroom hours are not sufficient.

Teacher 2. Of course; if the student number is high, I would organize group work. If our time is also limited, I would create an environment in which everyone can speak.

Teachers give equal opportunities for each student. 
5) Do you think affective factors play a role in reflective practice?

Teacher 1 . Since reflective teaching appeals to common sense, creativity comes to the fore and the student puts forth certain things.

Teacher 2. Of course, it helps and they learn through induction.

They agree with the idea of affective factors play a role in reflective thinking.

6) What do you think of moral aspects?

Teacher 1. Education needs to be carried out within the framework of mutual respect and love; if there are times in which the student is having trouble and the student is morally weak, it can affect others.

Teacher 2. The first goal of education needs to emphasize the moral aspect; the moral aspect varies according to age. If the lower classes are brought up well, the teachers get comfortable in higher classes. The moral state of the students can change from school to school.

Respect should be the primary aim.

Teacher 1 considers mutual respect is important among students. Teacher 2 thinks moral aspects should be given from the elementary classes (young ages).

7) Do you have the habit of keeping a reflection journal? Why or why not?

Teacher 1. There are no journals that I strictly follow but I follow them on the internet from time to time. I cannot find the time for that.

Teacher 2. There are no journals or journal subscription that I have. I usually keep up with culture and literature. Neither of the teachers keeps a reflection journal.

8) Do you try to observe some of your colleague's lessons? Why or why not?

Teacher 1 . There have been teacher colleagues the lessons of whom I have observed. But I cannot do this with any colleagues since some of them may be disturbed by another teacher being present in their class. I have always done this - I observe the students and relations outside as well as the classes of teachers who are good at their jobs. The large majority of my other colleagues/friends do not enter the classrooms of other teachers and make observations.

Teacher 2. I have not tried it, but I am in contact with my other colleagues. Actually, I am curious about it, too. But I have also never felt the need. We talk among each other from time to time. We ask each other questions when it becomes necessary.

It can be said that Teacher 1 rarely observed the other lessons, Teacher 2 never observed the other classes

9) Do you sometimes provide social topics for discussion in class?

Teacher 1. I do but this does not occur much in primary and secondary education. Children do not yield many ideas. I had worked in an Anatolian Teacher High School for a period of time and quite good social issues had been discussed there. I have not observed that other teachers do this much. I have given lessons in crowded classes with 40-45 students, there is not much room for discussion in crowded classrooms, yet still the students' level of knowledge and age are the most mercurial variable. And also, students ask us why they have to learn English and cannot get motivated since they are all too focused on securing jobs.

Teacher 2. I would bring it up, for instance environmental topics and national holidays. For instance, yesterday was New Year's Eve, it can be about a day like that, our culture and other cultures can be compared, students can be given such an opportunity. I say that reflective learning is beneficial both for the teacher and the student. Both of the teachers provide social topics with the students to discuss.

Both teachers provide different social topics for discussions

\section{Conclusion and Discussion}

Teachers are loaded with a charge of teaching each and every student in the most active way possible in order to reach the desired outcomes and goals in the dimension of education. Since societal and institutional factors require teachers to acquire more skills and carry out more tasks in professional terms, expectations from teachers have increased in recent years. Especially, teachers need to modernize themselves and keep up with the changes in order to adapt themselves to the changing system. So, how can teachers continue learning and improve themselves? While we are searching for the answers of these questions, theory and practice can be different from one another. Whereas some teachers behave reluctantly in improving themselves, some others are determined in terms of improving themselves. Teachers need to modernize themselves and keep up with the changes in order to 
adapt themselves to the changing system. At this juncture, "reflective learning" becomes an important factor in teachers' professional development.

When we analyze both male and female, they are indecisive about the items of "practical (pract)" subgroup whereas they both agree the items of "cognitive (cog)", "meta-cognitive (meta)", "critical thinking (crit)", "affective learning (affec)", "moral (moral)" and "classroom management (classman)" subgroups.

Depending on the test results, it can be said that, there are statistically significant differences between 3 profession levels by the mean attendance level of "critical thinking (crit)", "affective learning (affec)" and "classroom management (classman)". For the items of "critical thinking (crit)", the mean attendance level of student is lower than teacher and instructor. So, the students should be provided with exercises, additional materials and activities to some extent in order to develop their abilities in critical thinking.

Similarly, for the items of "affective learning (affec)", the mean attendance level of student is lower than teacher and instructor. Zeichner and Liston (1996), state that affective learning refers reflection about students, their linguistic and cultural backgrounds, their interests, and their readiness for assignments. For the items of "classroom management (classman)", the mean attendance level of student is lower than teacher and instructor. These results should be taken into consideration by the related authorities.

And as for the interview results with 2 teachers from secondary schools: both teachers in practicality know how to be a reflective teacher and they consider themselves to be reflective teachers; both of the teachers give equal opportunities for each student; they agree with the idea of affective factors playing a role in reflective thinking. Teacher 1 considers mutual respect is important among students. Teacher 2 thinks moral aspects should be given from the elementary classes; neither of the teachers keeps a reflection journal. These answers of the teachers are in line with the "relational approach ". It underlines the moral philosophy which puts into consideration the moral life around issues of personal character and how to treat other individuals (Hansen, 1998).

And lastly Teacher 1 rarely observed other lessons, whereas Teacher 2 never observed other classes. However, peer observation can be proposed to enhance activities among teachers; in addition to this, as was shown in a study by Karaaslan's (2003), the teacher can for the most part show opposition to being observed by a peer. One-off or repetitive activities such as a conference or a workshop are usually seen by teachers as away from reality and relevant classroom environments, hence impracticable and ineligible to the dimension of professional development being a continuous process (Büyükyavuz, 2016; Y1lmaz, 2015). For this reason, in preparing, presenting and contemplating on a class that is taught as a team, there is an obvious necessity for them to research the ways to collaborate with a colleague. This collaboration can help foreign language teachers' in reflective practices and prove a factor in establishing a more efficient and active environment for professional development.

Reflective learning is a way of thinking that consists of questions oriented towards themselves such as "what have I done, what am I doing, which feedbacks have I received, which presumable feedbacks will I receive?" As to be understood from this definition, reflective learning is necessary for teachers and learners in education in order for them to monitor themselves and make self-judgements. To this end the teachers' embrace of a reflective model is going to prove to be an example for their students and hence the students will embrace this model from early ages and acknowledge that evaluating their own processes is a part of learning.

\section{Suggestions}

This research includes 102 participants- instructors, teachers and students, in addition there are interviews with two school teachers. The aforementioned findings demonstrated there are some differences in perceptions of the participants towards reflective learning. It can be said that this study limited by 102 participants and 2 teacher interviews in Karabük Province, Turkey. So, the present study can provide suggestions and guidance for future research. The studies in order to get a more common conclusion and to develop some generalisations many more participants in various provinces of Turkey should be included for further studies. These studies will help teachers in teaching activities and this situation will lead to enhanced and increased student learning.

\section{References}

Adler, E. S., \& Clark, R. (2011). An invitation to social research: How it's done (4th ed.). Belmont, CA: Wadsworth.

Akbari, R., Behzadpoor, F., \& Dadvand, B. (2010). Development of English language teaching reflection inventory system, 38, 211-217.

Asbury, K., \& Plomin, R. (2014). G is for Genes. The Impact of Genetics of Education and Achievement. Wiley 
Blackwell.

Babbie, E. (2013). The practice of social research (13th ed.). Belmont, CA: Wadsworth, Cengage Learning.

Borg, S. (2011). Language teacher education. In J. Simpson (Ed.), The Routledge handbook of applied linguistics (pp. 215-228). London: Routledge.

Boud, D. (2001). Using journal writing to enhance reflective practice. In L. M. English, \& M. A. Gillen (Eds.) Promoting Journal Writing in Adult Education. New Directions in Adult and Continuing Education No. 90 (pp. 9-18). San Francisco: Jossey-Bass. https://doi.org/10.1002/ace.16

Burton, J. (2009). Reflective practice. In A. Burns, \& J. C. Richards (Eds.), The Cambridge guide to second language teacher education (pp. 298-308). New York: Cambridge University Press.

Büyükyavuz, O. (2016). Turkish ELT professionals' conference attendance motives: Why do they attend and what do they take back home? Journal of Education and Training Studies, 4(9), 135-143. https://doi.org/10.11114/jets.v4i9.1704

Coffield, F., Moseley D., \& Ecclestone, K. (2004). Learning styles and pedagogy in post-16 learning: A systematic and critical review. Cromwell Press Ltd. Trowbridge, Wiltshire.

Darling-Hammond, L., Wei, R. C., Andree, A., Richardson, N., \& Orphanos, S. (2009). Professional Learning in the learning profession: A status report on teacher development in the United States and abroad. Washington, DC: National Staff Development Council.

Davydov, V. V. (1990). Types of Generalization in Instruction: Logical and Psychological Problems in the Structuring of School Curricula. In J. Kilpatrick (Eds), Reston, VA: National Council of Teachers of Mathematics.

Dewey, J. (1933). How to think: A re-statement of the relation of reflective thinking to the education context. Boston: DC: Heath, \&Co.

Dewey, J. (1997). How we think. Chicago: Henry Regnery.

Dunn, R., \& Griggs, S. A. (1988). Learning Styles: A Quiet Revolution in American Secondary Schools. Reston, VA: National Association of Secondary School Principals.

Ellis, R. (2003). Task-based language learning and teaching. Oxford: Oxford University Press

Farrell, T. S. C. (2008). Reflective Practice in the Professional Development of Teachers of Adult English Language Learners. Caela Network Brief, October 2008.

Farrell, T. S. C. (2016). The teacher is a facilitator: Reflecting on ESL teacher beliefs through metaphor analysis. Iranian Journal of Language Teaching Research, 4(1), 1-10.

Friedman, P., \& Alley, R. (1984). Learning/Teaching Styles: Applying the Principles. Theory into Practice, 23(1), 77-81. https://doi.org/10.1080/00405848409543093

Han, T., \& Mazhoun, Z. (2017). What Demotivates Foreign EFL Teachers? A Case Study in Turkish Context. The Qualitative Report, 22(4), 1001-1014.

Han, T., Tanriöver, A. S., \& Şahan, Ö. (2016). EFL Students' and Teachers' Attitudes toward Foreign Language Speaking Anxiety: A look at NESTs and Non-NESTs. International Education Studies, 9(3), 1-11. https://doi.org/10.5539/ies.v9n3p1

Hansen, D. T. (1998). The moral is in the practice. Teaching and Teacher Education, 14(6), 643-655. https://doi.org/10.1016/S0742-051X(98)00014-6

Hanushek, E. A., \& Woessmann, L. (2008). The Role of Cognitive Skills in Economic Development. Journal of Economic Literature, 46(3), 607-668. https://doi.org/10.1257/jel.46.3.607

Karaaslan, A. D. (2003). Teachers' perceptions of self-initiated professional development: A case study on Baskent University English language teachers (Master's thesis).

Kember, D., Leung, D., Jones, A., Loke, A. Y., McKay, J. \& Sinclair, K. (2000). Development of a questionnaire to measure the level of reflective thinking. Assessment \& Evaluation in Higher Education, 25, 380-395. https://doi.org/10.1080/713611442

Kemmis, S. (2011). A self-reflective practitioner and a new definition of critical participatory action research. In N. Mockler, \& J. Sachs (Eds.), Rethinking Educational Practice through Reflexive Inquiry (Vol. 7., pp. 11-29). Dordrecht: Springer Netherlands. https://doi.org/10.1007/978-94-007-0805-1_2 
Kinsella, E. (2001). Reflections on reflective practice. Canadian Journal of Occupational Therapy, 68(3), 195-8. https://doi.org/10.1177/000841740106800308

Kumaravadivelu, B. (2003). Beyond methods macro strategies for language teaching. New Haven: Yale University Press.

Kumaravadivelu, B. (2006). Understanding language teaching: From method to post method. New Jersey: Lawrence Erlbaum Associates, Inc.

Lantolf, J. P., \& Poehner, M. E. (2014). Sociocultural Theory and the Pedagogical Imperative in L2 Education. Vygotskian Praxis and the Theory/Practice Divide. New York: Routledge. https://doi.org/10.4324/ 9780203813850

Larrivee, B. (2008). Development of a tool to assess teachers' level of reflective practice. Reflective Practice, 9(3), 341-360. https://doi.org/10.1080/14623940802207451

Lee, I. (2007). Preparing pre-service English teachers for reflective practice. ELT J, 61(4), 321-329. https://doi.org/10.1093/elt/ccm022

Mezirow, J. (1990). How Critical Reflection Triggers Transformative Learning. In J. Mezirow, \& Associates (Ed.). Fostering Critical Reflection in Adulthood San Francisco: Jossey-Bass (pp. 1-20).

Mezirow, J. (1991). Transformative Dimensions of Adult Learning. San Francisco, Jossey-Bass.

Richards, J. C., \& Farrell, T. S. C. (2005). Professional development for language teachers: Strategies for teacher learning. New York, NY: Cambridge University Press. https://doi.org/10.1017/CBO9780511667237

Richards, J. C. (1998). Beyond training: Perspectives on language teacher education. New York: Cambridge University Press.

Rivers, B. A., Richardson, J. T. E. \& Price, L. (2014). Promoting reflection in asynchronous virtual learning spaces: Tertiary distance tutors' conceptions. International Review of Research in Open and Distance Learning, 15(3) 215-231.

Ryder, J. (2012). Promoting reflective practice in continuing education in France. ELT Journal, 66(2), 175-183. https://doi.org/10.1093/elt/ccr032

Schön, D. A. (1983). The reflective practitioner: How professionals think in action (Vol. 5126). Basic books.

Schön, D. (1991). The reflective practitioner. Aldershot: Ashgate Publishing Ltd.

Semerci, N. (1999). Kritik Düşünmenin Mikro Öğretim Dersinde Eleştiri Becerisini Geliştirmeye Etkisi. (Fırat Üniversitesi Teknik Eğitim Fakültesi Örneği, Fırat Üniversitesi Sosyal Bilimler Enstitüsü: Yayınlanmamış Doktora Tezi. Elazı̆̆.

Tok, Ş. (2008). Yansıtıcı düşünmeyi geliştirici etkinliklerin öğretmen adaylarının öğretmenlik mesleğine yönelik tutumlarına, performanslarına ve yansıtmalarına etkisi. Eğitim ve Bilim, 33(149), 104-117.

Üğüten, S. D., \& Ekizer, F. N. (2017). Yabancı Dil Öğretiminde Yansıtıcı Öğrenme Nedir? In H. Yılmaz, E. Yücel, S. D. Üğüten, \& F. Şanal (Eds.), Farklı Yönleriyle Yabancı Dil Öğretimi. Çizgi Kitabevi Yayınları: 796.

Van Manen, M. (1991). The tact of teaching: the meaning of pedagogical thoughtfulness. Albany, NY: SUNY Press; London, Ont.: Althouse Press.

Vygotsky, L. S. (1978). Mind in Society: The Development of Higher Psychological Processes. (In M. Cole, V. John-Steiner, S. Scribner, \& Souberman (Eds.), Cambridge, MA: Harward University Press.

Whitton, D., Sinclair, C., Barker, K., Nanlohy, P., \& Nosworthy, M. (2004). Learning for teaching: Teaching for learning. Southbank, Victoria: Thomson Learning.

Xu, J., Li, B., \& Curtis, A. (2015). Validating an English language teaching reflection inventory in a Chinese EFL context. System, 49, 50-60. https://doi.org/10.1016/j.system.2014.10.014

Y1lmaz, Y. Y. (2015). Dealing with teacher resistance. In S. Borg (Ed.), Professional development for English language teachers: Perspectives from higher education in Turkey (pp. 37-46). Ankara, Turkey: British Council.

Zeichner, K. M., \& Liston, D. P. (1996). Reflective teaching: An introduction. Mahwah, New Jersey: Lawrence Erlbaum Associates Publishers.

Zuckerman, G. (2003). The Learning Activity in the First Years of Schooling. In A. Kozulin, B. Gindis, V. S. 
Ageyev, \& A. M. Miller (Eds.), Vygotsky's Educational Theory in Cultural Context (pp. 177-199). Cambridge University Press: New York. https://doi.org/10.1017/CBO9780511840975.011

\section{Copyrights}

Copyright for this article is retained by the author(s), with first publication rights granted to the journal.

This is an open-access article distributed under the terms and conditions of the Creative Commons Attribution license (http://creativecommons.org/licenses/by/4.0/). 